\title{
Hvordan vil journalistikkens rolle ændre sig som følge af borgerjournalistikken?
}

\section{AF ERIK KJAER LARSEN}

Borgerjournalistikken blev for alvor aktuel som genre i de konventionelle mediers web-versioner i 2006, som var året, hvor adskillige væsentlige danske og udenlandske medier lukkede op for mediebrugernes deltagelse gennem weblogs eller med invitationer om at indsende fotos, video m.m. Men 'borgerjournalistik' er mange ting og det er vigtigt at skille tingene ad; 'brugergenereret indhold' og 'blogging' er ikke nødvendigvis journalistik, og brugernes direkte engagement i produktion af indhold udfordrer mediernes traditionelt ubestridte rolle som gatekeepers for information. Der er set eksempler på, at borgere ved kollaborativ research kan afdække sager, som det ville være svært for etablerede medier at løfte alene (f.eks. 'Rather-gate'). Den sydkoreanske avis Ohmynews, lanceret i 2000 under sloganet 'Enhver borger er reporter', har haft massiv succes med sin kombination af traditionel, journalistisk produktion og såkaldt 'Citizen Reporting'. Ohmynews modellen blev i 2003 forsøgt omplantet til danske forhold, da tre tidligere ansatte på dagbladet Information lancerede det borgerjournalistiske medie Flix.dk. I takt med at medier integreres med internettet, og dermed bevæger sig fra 'en-til-mange' information mod 'mange-til-mange' kommunikation, vil der opstå nye hybrider mellem 'græsrodsjournalistikken' og den traditionelle journalistik. Borgerjournalistikken udgør dermed en voksende udfordring for pressen forstået som 'demokratiets vagt- 
hund' - den nye genre kan generelt set enten berige pressens samlede informations-udbud eller dekvalificere det. Men borgerjournalistikken er kommet for at blive og stiller nye, radikale krav og udfordringer til mediernes journalister, redaktører og brugere.

\section{Borgerjournalistik er mange ting}

Begrebet 'borgerjournalistik' er blevet et buzzword, der bruges i flæng om diverse interaktive medieformer, der hyppigt rubriceres i kategorierne New Media' og web 2.0 - to begreber, der i sig selv er næsten umulige at definere. En konstruktiv analyse/diskussion af fænomenet forudsætter en kort afklaring af, hvad begrebet dækker.

Som journalistisk arbejdsform eller genre blev Public Journalism eller Civic Journalism lanceret omkring 1988. Den oprindelige Public Journalism var et forsøg på fra centralt redaktionelt hold og inden for rammerne af traditionelle medieformater, at aktivere en given lokalbefolkning ved f.eks. at sende reportere ' $\mathrm{i}$ marken' for at engagere borgere i aktuelle politiske, miljømæssige eller andre problemstillinger. En af genrens pionerer, professor i journalistik ved New York University Jay Rosen, beskriver $\mathrm{Ci}$ vic Journalism som en bevægelse imod, at pressen tager en mere aktiv rolle mht., at engagere borgere i demokratiske processer. Civic Journalism skal kultivere demokratiet i stedet for at beskrive det - undersøge mulige løsninger i stedet for kun at blotlægge problemer. (Rosen 1999; Perry 2003). Et dansk eksempel kunne være Ekstra Bladets kampagne 'Istedgade', hvor en del af redaktionen blev flyttet ud i et lokalområde i København, hvorfra udsendte reportere beskrev de lokales verden og hverdag 'i øjenhøjde'.

Citizen Journalism eller Participatory Journalism er blevet den standende betegnelse for internetbaseret og typisk borger/bruger-drevet research eller afdækning af sager, der hyppigt har rod i nyhedshistorier fra de traditionelle trykte og elektroniske medier. Et eksempel der har fået status som 'participatory journalisms' gennembrud i mediesfæren er 'Rathergate':

8. september 2004 - to måneder før præsidentvalget i USA 
samme år - offentliggjorde den amerikanske tv-station CBS et indslag i programmet '6o Minutes' og dokumenter, der hævdedes at være bevis på, at præsident George Bush ved indflydelsesrige venners mellemkomst var sluppet for at gøre tjeneste i USA's National Guard i starten af 70'erne. I udsendelsen lagde den højt estimerede journalist Dan Rather sin troværdighed bag historien, da han sagde at 'dokumenternes autenticitet var blevet bekræftet af eksperter, som CBS havde været i kontakt med.' Få minutter efter at indslaget var vist, rejste bloggere tvivl om dokumenternes ægthed på debatforaet FreeRepublic.com. Sagen bredte sig til andre online-fora og et større kollaborativt research-arbejde blev iværksat - bl.a. en eftersøgning af eksperter i skrivemaskiner fra 70'erne. Ved fælles indsats lykkedes det amerikanske bloggere at sandsynliggøre, at dokumenterne var forfalskninger. Sagen blev refereret på det populære netmedie Drudge Report og sprang derfra tilbage til de etablerede medier. Washington Post bragte historien om de forfalskede dokumenter. I to uger fastholdt CBS at dokumenterne var ægte, men måtte efter en uvildig undersøgelse konkludere, at det var umuligt at bevise dokumenternes ægthed. Fire medarbejdere på CBS News blev efterfølgende fyret og Dan Rather tog sin afsked fra CBS News i foråret 2005, angiveligt som direkte konsekvens af indslaget.

Rathergate fremhæves af bl.a. Dan Gillmor (http://bayosphe re.com/blog/dangillmor) som et gennembrud for kollaborativ research/journalistik, idet det hævdes, at CBS aldrig havde trukket historien tilbage uden det massive engagement fra bloggere i kølvandet på tv-indslaget.

Begreberne 'Citizen Journalism' eller 'Participatory Journalism,' bruges også om det fænomen, at borgere via mobiltelefon eller email indsender fotos og fakta fra f.eks. ulykkesramte steder, sportsbegivenheder eller andet (Dan Gilmore, 2004). Formen inkorporeres i stigende grad af etablerede medier, bl.a. har CNN oprettet en sektion på deres website beregnet på brugergenereret indhold (http://edition.cnn.com/exchange). Det hidtil bedst kendte eksempel på styrken i denne form for borgerjournalistik er Metro-bombningerne i London 7. juli 2005, hvor materiale indsendt af vidner til terror-handlingerne var med til, at afdække for offentligheden, hvad der faktisk skete på dagen. 
Den model for borgerjournalistik, som danske Flix.dk på eksperimentel basis har prøvet at opdyrke, er direkte inspireret af det sydkoreanske Ohmynews.com, hvis stifter Oh Yeon-Ho bruger betegnelserne Citizen Reporting eller Guerilla Journalism om mediets brugergenererede indhold. I teorien indebærer Citizen Reporting, at borgerne sender artikler/kommentarer/klummestof til en central redaktion, som udvælger, redigerer og i nogle tilfælde afsætter redaktionelle ressourcer til professionel journalistisk opfølgning på sager, som borgere har rejst. Redaktionen kan afvise artikler og tager ansvaret for en prioritering af det indkomne stof og bevarer altså en gatekeeper funktion, meget lig den der kendes fra den traditionelle trykte og elektroniske presse. Med sine ca. 70 faste redaktionelle medarbejdere har Ohmynews desuden ressourcer til at skabe egne nyheder eller forfølge sager journalistisk, nøjagtig som det sker hos traditionelle medier.

Endelig findes der en mere autonom eller 'journalistfri' form for borgerjournalistik, der dyrkes blandt eliten i den såkaldte 'blogosphere', hvor borgere via deres egne weblogs (en art mikromedier der er knyttet til hinanden via diverse teknologier, RSS, Ping, trackback mm) udveksler information og holdninger på kryds og tværs i netværk, der udefra kan virke uoverskuelige.

Blogospheren har for de mest aktive brugere karakter af en alternativ nyhedskilde eller et banebrydende medieformat, der i sin struktur og funktionalitet er radikalt anderledes end de konventionelle trykte og elektroniske medier. Imidlertid stammer indholdet - den information der udveksles og diskuteres i blogospheren - hyppigt, men ikke altid, fra main stream medier.

De ovennævnte forskellige former for borgerjournalistik kan sagtens overlappe hinanden, og den kendsgerning at nye teknologiske platforme dukker på op internettet stort set dagligt (et eksempel blandt mange er den banebrydende mange-til-mange tv eller video-tjeneste YouTube (http:/ / youtube.com)) gør det umuligt, at give en nagelfast definition på, hvad begrebet borgerjournalistik reelt indeholder.

Men man kan konstatere, at: Internettet og mobiltelefoner $\mathrm{mm}$. er platforme for en radikalt ny og anderledes medie/formidlingskultur. 
At der overhovedet er fokus på borgerjournalistik i dag skyldes udbredelsen af nye elektronisk medier, der muliggør distribution af viden fra mange-til-mange, en væsentlig strukturel forskel på en-til-mange mediemodellen - 'massemedierne' - der satte deres enorme præg på det tyvende århundrede, i alle nuancer lige fra Hitlers virtuose udnyttelse af radio og film som propagandaapparat til popstjernefænomets globale udbredelse via radio og film. Ny teknologi, især internettet, gør mediebrugerne til potentielle indholdsleverandører, og derfor dækker begrebet brugergenereret indhold (User Generated Content, UGC) måske fra en overordnet synsvinkel bedre, hvad vi har med at gøre, når vi taler om borgerjournalistik.

\section{Flix.dk - borgerjournalistik på dansk}

Flix blev lanceret offentligt af Erik Kjær Larsen, Christian Lund og Klaus Holsting, tre tidligere kolleger fra dagbladet Information, i efteråret 2003. En pilotudgave af webavisen blev testet af en lukket kreds fra april 2003. Inspirationen til Flix.dk var en artikel på wired.com om den sydkoreanske borgerjournalistiske avis Ohmynews.com.

Det første år producerede redaktionens medlemmer mindst en artikel dagligt, det være sig enten en anmeldelse, en nyhedshistorie, en lederlignende artikel eller en baggrundsartikel. Det vil sige stof, der i høj grad faldt indenfor rammerne af de velkendte journalistiske genrer. Materiale modtaget fra læserne var - erfarede vi snart - formmæssigt markant anderledes, typisk skrevet i jeg-form og hyppigt stærkt holdningspræget - nært beslægtet med den subjektive form, der kendes fra weblogs.

Ideen med Flix.dk var og er, at tilbyde nettets mange skribenter (amatør-journalister om man vil) et redaktionelt modspil og via en redaktionel proces sikre den højest mulige standard mht. faktatjek, gennemarbejdet research, prioritering af stof efter væsentlighed m.v. Flix.dk er kort sagt et forsøg på at forene det bedste fra 'blogospheren' eller den spirende mange-til-mange kommunikationskultur med det bedste fra den traditionelle presse de klassiske journalistiske dyder. 


\section{Borgerjournalistik versus traditionel journalistik}

Selv om Flix.dk med mellemrum bringer egentlige nyhedshistorier, har indholdet for det meste karakter af debat/opinionsstof eller personlige fortællinger fra hverdagen, arbejds- eller familielivet. Som regel tager borgernes indsendte artikler udgangspunkt i sager, der i forvejen verserer i medierne, men i enkelte tilfælde starter skribenterne på eget initiativ artikelserier eller debatter, som afviger markant fra hvad main stream medier tilbyder sine læsere/seere/lyttere.

Eksempelvis opstod der på et tidspunkt spontant en heftig debat om 'Det enkle liv' i det åbne forum på Flix.dk. Serien, eller tråden som det hedder i netjargonen, drejede sig om hvordan man undgår stress i dagligdagen og indretter sig efter værdier som samvær, arbejdsglæde og tid til børn og familieliv. Flix har også bragt artikler om graffiti og alternative musikfestivaler, og $\mathrm{i}$ det hele taget er mediet et oplagt opsamlingssted for nicheprægede stofområder. I enkelte tilfælde har Flix.dk været et aktivt led i den etablerede mediefødekæde. F.eks. da Flix som det første medie beskæftigede sig med den såkaldte 'Keld Bach' sag.

Keld Bach-sagen startede da grafikeren og bloggeren Keld Bach i februar 2004 fra Antipiratgruppens advokater modtog et brev, der gav Bach valget mellem at underskrive en erklæring på, at han var kriminel eller stille op imod et sagsanlæg, som kunne have kostet ham en mindre formue. Årsagen var, at Bach havde bragt et link til en muligvis ulovlig hjemmeside i forbindelse med omtale af den kontroversielle musikudgivelse The Grey Album af den amerikanske rapper DJ Danger Mouse. Efter at Flix.dk havde beskrevet sagen som et groft anslag mod ytringsfriheden, fik den omtale i bl.a. dagbladet Information, Berlingske Tidende og på Pl's Kulturnyt. Bach modtog midt i marts 2004 en uforbeholden undskyldning fra Jacob Plesner fra Antipiratgruppen, der året efter modtog en skarp irettesættelse fra Advokatnævnet for at have „tilsidesat god advokatskik“.

I efteråret 2004 modtog Flix.dk et indlæg fra den somaliske musiker Zak Osman. Artiklen beskrev hvordan grupper af fundamentalistiske islamister på Nørrebro ved chikane havde forhindret afholdelsen af en koncert, som Osman var medarrangør på. 
Artiklen på Flix.dk førte til omtale i Politiken og var få dage senere del af en hovedhistorie på TV2 Nyhedernes 22-udsendelse.

Det er (eller var måske især før sagen om Muhammed-tegninger satte mere fokus på problemet) sjældent at medlemmer af etniske mindretal kommer til orde i danske medier, og selv om Zak Osmans artikel var stærkt subjektiv i sin beskrivelse af specifikke begivenheder, kan man vove den påstand, at personlige beretninger af den art bidrager til et mere fuldkomment og dermed objektivt mediebillede af, hvad der rører sig i samfundets marginale områder.

På grund af det åbne format på en webavis som Flix.dk, hvor enhver via kommentarfunktionen kan byde ind med rettelser af faktuelt forkert information og/eller tilføje links eller citater der opdaterer eller supplerer indholdet af en given artikel, siger vores erfaring, at slutresultatet får en høj grad af faktuel korrekthed. Faktuelt forkerte oplysninger, der er sivet gennem det redaktionelle filter, får ikke lov til at stå uimodsagt. På Flix.dk hersker et element af vidensdeling og man kan næsten sige kollaborativ research. Summen af subjektive fortællinger giver tilsammen et multifacetteret og dermed i en vis forstand mere sandfærdigt objektivt - billede af hverdagen og virkeligheden i Danmark, som den erfares af borgerne, end det der kolporteres af de dagsordensættende mainstream medier. Flix har et ikke vanvittig stort (ca. 33.000 unikke brugere i maj 2006) brugergrundlag, men til gengæld er det meget bredt - der er både akademikere, skoleelever, pensionister, taxachauffører, skolelærere med mange flere som skriver til Flix, kort sagt borgere fra 'all walks of life'.

På Flix.dk har vi erfaret, at mediets format skaber et kraftig element af 'community' blandt brugerne - et samvær om debat/ formidling, som interessant nok lader til at gå på tværs af partiskel og faglige tilhørsforhold. Mediet engagerer sine brugere og har ind imellem mere karakter af forsamlingshus eller 'agora' end avis.

Hvis man lægger sin lokale medieoptik til side for en stund, er der ingen tvivl om at borgerjournalistik, enten i form af blogging eller efter Ohmynews-modellen, har sin største berettigelse i lande eller regioner, hvor den information, der tilflyder borgerne er stærkt censureret eller propagandapræget. I lande som Kina og 
Iran blogges der flittigt, til trods for at det er ulovligt og kan medføre fængsels- eller dødsstraf. I den sammenhæng er det amerikanske medieinitiativ globalvoicesonline.org værd at nævne.

Globalvoicesonline.org har med rødder i Berkman Center for Internet and Society etableret et globalt netværk af oversættere og 'blogspejdere', hvis opgave består i at følge og finkæmme weblog-miljøet i diktaturstater med henblik på at oversætte og videreformidle nyheder/fortællinger om, hvad der reelt foregår enten på borgernes private/personlige plan eller i et større politisk perspektiv i de pågældende lande/regioner (http://globalvoices online.org).

Flix.dk blev lanceret bl.a. som en reaktion på at danske main stream medier tilsyneladende drev medievirksomhed ud fra en forventning om at internettet før eller siden ville forsvinde igen. Det forekom os, at man fra centralt beslutningshold i mediebranchen enten var bange for at miste grebet om gatekeeper-rollen, eller følte sig magtesløs overfor de tekniske og ressourcemæssige udfordringer, der er forbundet med interaktiv journalistik/formidling/kommunikation. Men meget har ændret sig på den front siden 2003.

\section{Brugergenereret indhold og den journalistiske kvalitet/objektivitet}

Tendensen er i de senere år gået imod at flere og flere større danske medier indoptager elementer af borgerjournalistik i deres medievirksomhed, i sagens natur først og fremmest på deres webudgaver.

Fagbladet Ingeniøren var blandt de første på banen med journalist Kurt Westh Nielsens weblog, der hurtigt blev et af de mest læste elementer på ing.dk. Om der er tale om borgerjournalistik kan man diskutere, men webloggen skabte en dialog med avisens læsere, som uundgåeligt i sidste ende sætter sit præg på også den trykte udgave af fagbladet. Dagbladet Information har på avisens hjemmeside lukket op for læsernes kommentarer og anmeldelser, og der skrives løbende weblog fra redaktionsmøderne på bladet. Dagbladet Politiken har for nylig ansat en blog-redaktør, og initativet vil med stor sandsynlighed skabe et kraftigere islæt 
af 'community' og loyalitet blandt avisens kernelæsere, måske endda især blandt de yngre læsere, som avisbranchen har brugt enorme summer på at indfange og fastholde.

Hvad gratisavis-boomet på sigt vil betyde for kvalitets-dagbladenes kerneydelse - journalistik af høj kvalitet og faglig satsning på redelighed og tilstræbt objektivitet - kan man indtil videre kun gisne om, men vil man være pessimist, kan man frygte, at gratisaviserne fremover vil blive præget af 'gratis' og af konkurrencehensyn i stigende grad overfladisk eller livsstilspræget stof, måske med elementer af sensationspræget subjektivitet - 'Realitynews' leveret af borgerne/læserne/brugerne stort set uden omkostninger for mediehusene.

Tendensen ser man i nogen grad hos gratisavisen Urban, der stiller weblogs til rådighed for læserne og bringer uddrag fra diverse weblogs i avisens papirudgave - men typisk uddrag, der er uden politisk, faglig eller informationsmæssig tyngde. Med andre ord borgerjournalistik som underholdning.

Sydkoreanske Ohmynews har ved flere lejligheder demonstreret, at et borgerjournalistisk medie kan have væsentlig gennemslagskraft, og avisen regnes i dag for Sydkoreas sjette mest indflydelsesrige medie. Men hvilken retning borgerjournalistikken vil tage efterhånden som den i stigende grad indoptages som gængs format i vestlige medier, og hvilken gennemslagkraft den vil få, er det efter min mening for tidligt, at sige noget konkret om.

Men hvis borgerjournalistikken i sit møde eller sammensmeltning med main stream medier skal udvikle sig til noget samfundsgavnligt, og det journalistfaglige ideal om tilstræbt objektivitet skal bibevares i processen, kræver det, tror jeg, særlig opmærksomhed og debat blandt journalister og mediefolk generelt om såvel de nye genrer/formater, der vil opstå i mødet med borgernes røst 'nedefra' og den professionelle presses 'oppefra'.

Efterhånden findes der en del praktiske eksempler, som man kan skele til. Flix.dk er grundet manglende finansiel rygdækning stadig kun er en primitiv beta-udgave af den model, som var og er målet. Men beslægtede medier dukker for tiden op som paddehatte på den vestlige mediearena: Den rent webbaserede tyske avis netzeitung.de har lanceret en 'Readers Edition', som konceptmæssigt ligger tæt på Ohmynews (http://www.netzeitung. 
de). På http://www.readers-edition.de er det ikke primært journalister, der optræder som redaktører eller 'coaches' - mediets brugere kan ansøge om at blive 'moderatorer', og i skrivende stund er der 13 sådanne, hvis opgave det er, at udvælge og redigere det indkomne materiale. CNN har på sin hjemmeside lanceret et forum for borgerjournalistik - eller måske mere præcist User Generated Content (UGC) (http://edition.cnn.com/exchan ge). I Frankrig har firmaet Cybion lanceret det engelsksprogede Agoravox, som er et forsøg på, at skabe et paneuropæisk forum for borgerjournalistik (http://www.agoravox.com). I Israel har journalisten Michael Weiss med venturekapital i ryggen startet det borgerjournalistiske medie Scoop (http://scoop.co.il). Craigslist et webbaseret annoncemarked (a la Den Blå Avis), som i stigende grad er platform for Participatory Journalism (http:// craigslist.com). Backfence.com er et amerikansk forsøg på, at skabe en ny type internetbaseret 'lokalavis', hvor tekster og fotos mm. leveres af borgere. Indholdet indekseres efter lokalområder (http://backfence. com). Assignment Zero er en ambitiøs amerikansk web-platform for borgerjournalistik, som blev startet foråret 2007 af NewAssignment.net i samarbejde med Wired.com og Newsvine (http://zero.newassignment.net/)

\section{Afslutning}

Borgerjournalistikken - uanset hvilken form det forekommer i kan og bør efter min mening ikke erstatte eller af sparehensyn udsulte den professionelle journalistik af høj kvalitet. Men hvis de netbårne, journalistiske græsrødder møder den etablerede presse inden for gennemtænkte rammer, kan resultatet meget vel blive en mere alsidig, grundig og objektiv journalistik, dels fordi langt flere kilder - i princippet enhver borger - kan byde direkte ind med fakta, fotos eller skrevne indlæg, dels fordi den åbenhed/gennemsigtighed, som et 'Open Source' baseret kildenet repræsenterer i princippet er overlegent i forhold til det lukkede, eksklusive kildenetværk, journalister traditionelt har benyttet.

2006 blev året hvor de etablerede medier for alvor tog internettets interaktive muligheder op som en seriøs udfordring. Ekstra 
Bladet lancerede sin blog-tjeneste EB-blog samt sit bud på Citizen Journalism 'Læserbladet'. Nyhedsavisen tilbyder læserne egen weblog på Avisen.dk, TV2 har åbnet for blogging på deres hjemmeside og Politiken har ansat en blog-redaktør. Det er svært at danne sig et overblik over tendenser i eller konsekvenser af en så relativt ny mediekultur. I lyset af mine erfaringer fra Flix.dk tror jeg ikke, at borgerjournalistik/blogging vil have den store indflydelse på endsige kunne erstatte professionel journalistik. Borgerjournalistikken kan i heldigste fald blive en berigelse og et supplement til det eksisterende presseudbud. Borgerjournalister/bloggere er - jvf. min erfaring fra de næsten 5000 artikler Flix.dk har modtaget fra borgere siden projektets start i 2003 langt fra mediefagligt rustede til, at kunne levere dybdeborende journalistik eller dagsordensættende nyhedsjournalistik, der kan konkurrere med den professionelle i gennemslagskraft. Ikke desto mindre kan borgerjournalister ideelt set både påvirke nyhedsdagsordnen og lejlighedsvis have direkte indflydelse på den, og muligheden for at enhver kan komme til orde i et offentligt medierum, kan kun styrke den enkelte borgers engagement $\mathrm{i}$ samfundet. Desuden er det stærke element af vidensdeling - den kendsgerning at bloggere/borgerjournalister i stor stil deler links og referencer med hinanden - med til at styrke mediernes webudgavers værdi som kilder til almen viden.

Set med de pessimistiske briller er der risiko for, at borgerjournalistik indoptages af de etablerede medier som billigt, selvgenererende indhold og opdyrkes som en slags 'Reality News' præget af overfladiske og samfundsmæssigt irrelevante historier. Man kan også frygte, at der kommer et vist præg af narcissisme over nyhedsudbuddet, $\mathrm{i}$ takt med at flere og flere mediebrugere får mulighed for at sætte egne dagsordner. Der er ingen forhåndsgaranti for, at borgernes bidrag til mediebilledet generelt vil repræsentere en overordnet samfundsinteresse, og værdien af borgerjournalistik afhænger i høj grad af hvilken optik, man betragter den ud fra. Fra en ren markedsbetragtning er underholdningsværdien og brugernes personlige engagement som bloggere eller borgerjournalister på et givent medies hjemmeside afgjort et plus. Ser man derimod pressen som 'demokratiets vagthund' er den manglende kildekontrol, stave- og sproglige fejl samt de 
mange, for en bredere kreds, uvæsentlige blog-indlæg samt selve uoverskueligheden ved navigation i den kolossale informationsmængde i det bruger-genererede nyhedsunivers et stort minus eller en væsentlig udfordring for webmediernes redaktører.

Hvilket scenarie der i sidste ende bliver dominerende afhænger efter min mening i høj grad af, hvordan medierne - de medier der har brugergrundlaget, motivationen og de økonomiske ressourcer til at løfte kvaliteten i borgerjournalistikken - forholder sig til og indarbejder genren i deres formater.

Set fra en teknologisk synsvinkel er der grund til optimisme, fordi internettet skaber alle tænkelige forudsætninger for at enhver til enhver tid kan finde den information og de nyheder, som vedkommende søger/ønsker. Den dygtige surfer - eller kritiske mediebruger - vil i stigende grad blive sin egen redaktør og kunne vælge og vrage mellem uanede mængder af information, hvilket stiller skærpede krav til samme brugers mediekundskaber og kritiske sans. Til gengæld vil mindre trænede eller motiverede mediebrugere hurtigt kunne fortabe sig i brugen af kraftigt stimulerende sociale online-netværk, der kan ligne nyhedsmedier eller debatfora til forveksling, men som ikke har andet formål end, at være stimulerende og tiltrækkende af hensyn til annonce-eksponering.

I fremtidens medielandskab, hvor informationsmængden og dialogen med både læser/seere/brugere/borgere samt kilder og eksperter vil blive mangedoblet og i stigende grad foregå et i åbent, fuldt offentligt medie-rum, vil den professionelle journalist skulle bruge mere tid på at sortere væsentligt fra uvæsentligt samt forsvare sine professionelle dispositioner i en direkte dialog med både læsere/seere/lyttere og kilder. Til gengæld vil medier, der tager udfordringen fra 'journalistikkens græsrødder' alvorligt, kunne vinde meget ved løbende at udvikle historier i tæt samspil med brugerne, som vil kunne supplere med nye vinkler og viden, som den klassiske skrivebords-journalist udstyret med telefon og en liste med telefonnumre på eksperter og kilder i mange tilfælde ville overse. 


\section{REFEREN CER}

Jay Rosen (1999). What are Journalists for? New Haven \& London: Yale University Press.

David K Perry (2003). Roots of Civic Journalism, Lanham: Rowman and Littlefield.

Dan Gilmore (2004). We the Media: Grassroots Journalism by the People, for the People, Uden sted: O'Reilly Media. 